\title{
Acceleration of Orthodontic Tooth Movement
}

\author{
Rabab Alsabbagh* \\ Department of Orthodontics and Head of Orthodontics, Syria \\ *Corresponding author: Rabab Alsabbagh, Department of Orthodontics and Head of Orthodontics, faculty of Dentistry, \\ Syria
}

\begin{tabular}{|c|c|}
\hline ARTICLE INFO & ABSTRACT \\
\hline Received: 蒌 April 12, 2019 & Citation: Rabab Alsabbagh. Acceleration of Orthodontic Tooth Movement. Biomed J Sci \& \\
\hline Published: 慧 April 22, 2019 & Tech Res 17(2)-2019. BJSTR. MS.ID.002978. \\
\hline
\end{tabular}

\section{Introduction}

The duration of orthodontic treatment is one of the issues patients complain about most, especially adult patients which maybe the reason beyond many refusals of undergoing orthodontic treatment [1]. To shorten orthodontic tooth movement times, various attempts have been made local or systemic administration of medicines, [2-5] mechanical or physical stimulation, [6,7] and oral surgery, including gingival fiberotomy, [8] alveolar surgery, [9] and distraction osteogenesis [1]. In 1959, Köle described a surgical procedure involved a radicular corticotomy and supraapical osteotomy. This was accomplished by creating blocks of bone with vertical buccal and lingual corticotomies and a supraapical horizontal osteotomy connecting cut to enable rapid movement of the dentoalveolar process $[10,11]$. Suya believed that a corticotomy was able to make tooth movement faster because of the simultaneous movement of the tooth and the surrounding bone block [12].

Wilcko et al. in a series of case reports [10,13] mentioned that rapid orthodontics with corticotomies could increase tooth movement by increasing bone turnover, decreasing bone density $[14,15]$ and decreasing hyalinization of the periodontal ligament [1]. Frost found a direct correlation between the severity of bone corticotomy and/or osteotomy and the magnitude of the healing response, leading to accelerated bone turnover at the surgical site. This was called "Regional Acceleratory Phenomenon" (RAP). RAP was explained as a temporary stage of localized soft and hardtissue remodeling that resulted in rebuilding of the injured sites to a normal state through recruitment of osteoclasts and osteoblasts via local intercellular mediator mechanisms involving precursors [16]. Bogoch found a five-fold increase in bone turnover in a long bone adjacent to a corticotomy surgery site. In alveolar bone adjacent to corticotomy, there is a marked increase in regional bone turnover due to activation of new remodeling. Calcium is released from alveolar bone creating a reversible demineralized condition (alveolar osteopenia) resulting in a decrease in bone mass (mineral content or density) but no change in bone volume [17]. According to Hajji, the active orthodontic treatment times in patients with corticotomies were 3 to 4 times shorter compared to those of patients without corticotomies [18]. According to Al Naoum et al. Tooth movement velocities following corticotomies were 2-4 times faster on the experimental side than on the control side particularly during the early stage after corticotomy [19]. Nowzari et al. stated in their case report, using a modified surgical approach and limiting the corticotomy to the buccal and labial aspects, that the PAOO was an effective treatment approach in adults in decreasing treatment duration and in reducing the risk of root resorption. Final lateral cephalometric analysis showed proclination of the upper and the lower anterior teeth [20]. Aljhani and Zawawi [21] applied the combined non-extraction orthodontic treatment with the corticotomy technique in an adult patient, 25 years old, with severely crowded dental arches to accelerate tooth movement and shorten the treatment time. Buccal and lingual corticotomies with alveolar augmentation procedure in the maxilla and the mandible were performed. The total treatment time was 8 months with no adverse effects observed at the end of active treatment. The addition of the decortication procedure to the conventional orthodontic therapy decreased the duration of treatment significantly. Compared with traditional orthodontic treatment, the PAOO procedure that combines the advantages of corticotomy-facilitated orthodontics and periodontal alveolar augmentation offers the advantage of achieving the desired results in a significantly reduced treatment duration [22].

\section{References}

1. Iseri H, Kisnisci R, Bzizi N, Tuz H (2005) Rapid canine retraction and orthodontic treatment with dentoalveolar distraction osteogenesis. Am J Orthod Dentofacial Orthop 127(5): 533-541. 
2. Lee W (1990) Experimental study of the effect of prostaglandin administration on tooth movement with particular emphasis on the relationship to the method of PGEI administration. Am J Orthod Dentofacial Orthop 98(3): 231-241.

3. Mohammed AH, Tatakis DN, Dziak R (1989) Leukotrienes in orthodontic movement. Am J Orthod Dentofacial Orthop 95(3): 231-237.

4. Yamasaki K (1983) The role of cyclic AMP, calcium and prostaglandins in the induction of osteoclastic bone resorption associated with experimental tooth movement. J Dent Res 62(8): 877-881.

5. Collins MK, Sinclair PM (1998) The local use of vitamin D to increase the rate of orthodontic tooth movement. Am J Orthod Dentofacial Orthop 94(4): 278-284.

6. Davidovitch Z, Finkelson MD, Steigman S, Shanfeld JL, Montgomery PC Korostoff E (1980) Electric currents, bone remodeling, and orthodontic tooth movement. II. Increase in rate of tooth movement and periodontal cyclic neucleotide levels by combined force and electric current. Am J Orthod 77(1): 33-47

7. Darendeliler MA, Sinlcair PM, Kusy RP (1995) The effect of samariumcobalt magnets and pulsed electromagnetic fields on tooth movement. Am J Orthod Dentofacial Orthop 107(6): 578-588.

8. Tuncay OC, Killiany DM (1986) The effect of gingival fiberotomy on the rate of tooth movement. Am J Orthod 89(3): 212-215.

9. Liou EJW, Huang CS (1998) Rapid canine retraction through distraction of the periodontal ligament. Am J Orthod Dentofacial Orthop 114(4): 372-382.

10. Wilcko MH, Wilcko MT, Bouquot JE, Ferguson DJ (2001) Rapid orthodontics with alveolar reshaping: two case reports of decrowding. Int J Periodontics Restorative Dent 21(1): 9-19.

11. Köle H (1959) Surgical operation on the alveolar ridge to correct occlusal abnormalities. Oral Surg Oral Med Oral Pathol Oral RadiolEndod 12(5): 515-529.

12. Suya H (1991) Corticotomy in orthodontics. Am J Orthod Dentofacial Orthop 14: 207-226.

ISSN: 2574-1241

DOI: 10.26717/BJSTR.2019.17.002978

Rabab Alsabbagh. Biomed J Sci \& Tech Res

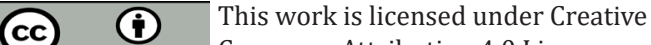

Commons Attribution 4.0 License

Submission Link: https://biomedres.us/submit-manuscript.php
13. Wilcko WM, Ferguson DJ, Bouquot JE, Wilcko MT (2003) Rapid orthodontic decrowding with alveolar augmentation: case report. World J Orthod 4(3): 197-205.

14. Verna C, Dalstra M, Melsen B (2000) The rate and the type of orthodontic tooth movement is influenced by bone turnover in a rat model. Eur J Orthod 22(4): 343-352.

15. Verna C, Melsen B (2003) Tissue reaction to orthodontic tooth movement in different bone turnover conditions. OrthodCraniofac Res 6(3): 155163.

16. Frost HM (1989) The biology of fracture healing. An overview for clinicians. Part I. ClinOrthop Related Res 248: 283-293.

17. Bogoch E, Gschwend N, Rahn B, Moran E, Perren S (1993) Healing of cancellous bone osteotomy in rabbits - Part I: regulation of bone volume and the regional acceleratory phenomenon in normal bone. J Orthop Res 11(2): 285-291.

18. Hajji SS (2000) The influence of accelerated osteogenic response on mandibular decrowding [thesis]. St Louis: St Louis University.

19. Al-Naoum F, Hajeer MY, Al-Jundi A (2014) Does alveolar corticotomy accelerate orthodontic tooth movement when retracting upper Canines? A split-mouth design randomized controlled trial. J Oral Maxillofac Surg 72(10): 1880-1889.

20. Nowzari H, Yorita F, Chang H (2008) Periodontally accelerated osteogenic orthodontics combined with autogenous bone grafting. Compend Contin Educ Dent 29(4): 200-218.

21. Aljhani A and Zawawi K (2012) Non-extraction Treatment of severe crowding with the aid of corticotomy-assisted orthodontics. Case Rep Dent pp. 694-527.

22. Al-Naoum F, Al-Sabbagh R, Al-Jundi A (2014) Periodontally accelerated osteogenic non-extraction orthodontics versus conventional extractionbased orthodontics for severe decrowding cases: A randomized controlled trial. International Arab Journal of Dentistry (IAJD).

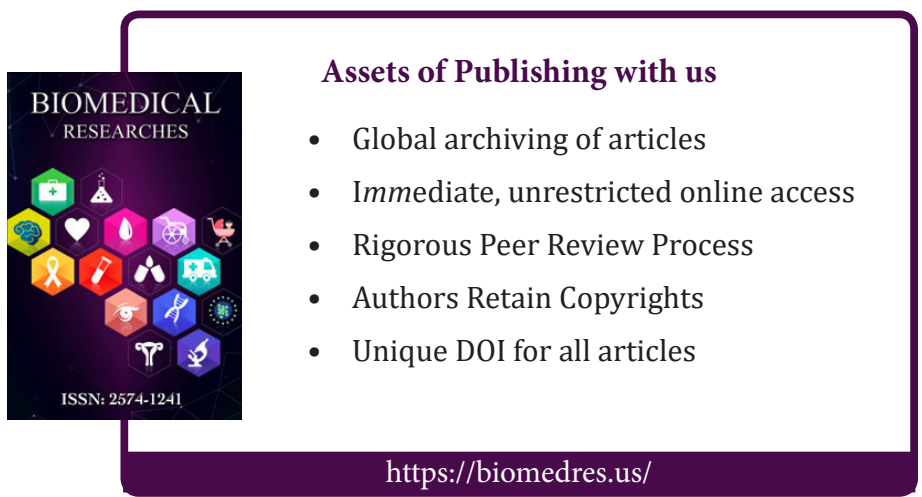

